\title{
Weed Mix Pollen Antigen IgA Antibody Measurement
}

National Cancer Institute

\section{Source}

National Cancer Institute. Weed Mix Pollen Antigen IgA Antibody Measurement. NCI

Thesaurus. Code C130108.

A measurement of the weed mix pollen antigen IgA antibody in a biological specimen. 